\title{
Penelitian Pendahuluan (Preliminary Research) Intrusi Air Laut di Desa Sriwulan, Demak, Indonesia
}

\author{
Edy Trihatmoko $^{1^{*}}$, Husein Sadewa Wiguna ${ }^{2}$, Tjaturahono Budi Sanjoto ${ }^{1}$, Juhadi ${ }^{1}$, \\ Hariyadi $^{2}$, Sugeng Widada ${ }^{2}$, David Milliano Josanova ${ }^{1}$, Abd. Basith Mukhlas ${ }^{1}$, \\ dan Muhammad Taqy ${ }^{1}$ \\ ${ }^{1}$ Department of Geography, Universitas Negeri Semarang, Indonesia \\ Jl. Ir. Sutami No.36, Kentingan, Kec. Jebres, Kota Surakarta, Jawa Tengah 57126 \\ Email:*edytrihatmoko@mail.unnes.ac.id \\ ${ }^{2}$ Departement Of Oceanography, Universitas Diponegoro, Indonesia \\ Jl. Prof. Sudarto, SH., Tembalang, Semarang, Central Java (50275) Indonesia
}

\begin{abstract}
ABSTRAK
Intrusi air asin adalah suatu peristiwa penyusupan air asin ke dalam akuifer di mana air asin menggantikan atau tercampur dengan air tanah tawar yang ada di dalam akuifer. Permasalahan yang timbul dengan adanya intrusi air asin adalah rusaknya air tanah akibat kontaminasi mineral garam laut. karakteristik geomorfologi wilayah Desa Sriwulan, Kecamatan Sayung, Kabupaten Demak yang cenderung datar dan sifat materialnya yang didominasi oleh sedimen alluvial membuat daya resapan air laut semakin tinggi. Penggunaan air tanah yang telah mengalami intrusi untuk dikonsumsi maupun kegiatan lain untuk keperluan domestik, dapat mengganggu kesehatan, karena air ini telah mengandung senyawa garam yang tinggi dan dapat mengganggu metabolisme yang terjadi di dalam tubuh manusia. Penelitian ini bertujuan untuk mengetahui distribusi intrusi air asin. Pengukuran geolistrik dilakukan pada tanggal 24 - 25 April 2020. Pengukuran intrusi air asin sendiri diolah dengan menggunakan software Progress untuk mendapatkan interpretasi bawah permukaan menggunaan metode geolistrik resistivitas. Berdasarkan Hasil interpretasi penampang litologi, intrusi air asin terjadi pada kedalaman 0 - $30 \mathrm{~m}$ yang memiliki litologi lempung dan lanau pada seluruh lokasi pengukuran di Desa Sriwulan.
\end{abstract}

Kata Kunci: air tanah, intrusi air asin, Sayung

\section{PENDAHULUAN}

Air merupakan salah satu sumber daya alam yang memiliki peranan penting bagi mahluk hidup, utamanya adalah air bersih. Hal ini, sesuai dengan target sustainable development goals (SDGs) yang dirumuskan oleh United Nation (UN) pada nomor 6 tentang Clean Water and Sanitation. Artinya, pada tahun 2030 nanti kebutuhan air bersih harus terpenuhi (Fletcher et al., 2018). Sumber air bersih yang paling dominan digunakan oleh masyarakat adalah air tanah. Hal ini terjadi karena dominasi air tawar di permukaan bumi sebesar 30\% adalah air tanah. Namun demikian, tidak semua masyarakat mampu mengakses air tanah, baik karena kebijakan yang berlaku di wilayah setempat maupun karena kondisi fisik wilayah setempat yang tidak mendukung. Salah satu wilayah yang sulit untuk memperoleh air tanah adalah pada wilayah pesisir. Beberapa wilayah melarang penggunaan air tanah di wilayah pesisir karena akan merusak lingkungan pesisir. Rusaknya lingkungan wilayah pesisir adalah efek collateral yang muncul akibat menurunnya muka air tanah dari proses pengambilan air tanah yang berlebihan, yang kemudian diikuti dengan penggenangan lahan yang dapat memperparah intrusi air asin (Trihatmoko, 2020). Di Indonesia, intrusi air asin di wilayah pesisir telah terdeteksi di beberapa daerah diantaranya pantai dan pesisir Jakarta, Semarang, dan beberapa wilayah lain di pantai utara Jawa, Denpasar, Medan dan daerah-daerah pesisir lainnya, akibat pemanfaatan air tanah secara berlebihan (Hendrayana, 2002; Ode, 2011).

Intrusi air asin merupakan dampak penurunan muka air tanah di wilayah pesisir, proses ini disebabkan oleh adanya cone of depression dan ascension dalam sistem air tanah. Dalam keadaan alami air tanah tawar mengalir ke lautan lewat akuifer-akuifer di daerah pantai yang berhubungan dengan lautan pada pantai yang menjorok ke laut. Tetapi karena meningkatnya kebutuhan akan air tawar, maka aliran air tanah tawar ke arah laut menurun, atau bahkan sebaliknya, air laut menyusup 
masuk ke dalam akuifer daratan (Irham et al., 2006; Mas Pla et al., 2014). Penyusupan ini akan menyebabkan air tanah tidak dapat dimanfaatkan, dan sumur yang memanfaatkannya terpaksa ditutup atau ditinggalkan (Octonovrilna \& Pudja, 2009). Semakin meningkatnya konsentrasi penduduk global di kawasan pesisir, dapat memicu permasalahan lingkungan disegala aspek baik ekologi, sosial dan ekonomi.

Sayung merupakan salah satu kecapatan di Kabupaten Demak yang mengalami cemaran air tanah oleh air asin, Desa Sriwulan menjadi salah satu dengan dengan dampak yang signifikan. Pada wilayah tersebut dampak banjir rob pun terjadi cukup parah (Nugroho et al., 2020). Menurut survei responden yang telah dilakukan, $20 \%$ air tanah yang digunakan untuk memenuhi kebutuhan warga di Kecamatan Sayung terasa asin (Desmawan \& Sukamdi, 2012). Hal ini disebabkan oleh dampak banjir rob yang semakin meluas dan genangannya mencapai 6-8 jam perharinya. Rob yang terjadi di Desa Sriwulan tidak hanya menambah parahnya intrusi air asin, namun juga menyebabkan perubahan garis pantai sebanyak $-553.3-20.4 \mathrm{~m} /$ tahun (Meyer et al., 2019). Genangan yang terjadi oleh banjir rob juga tercatat hingga 0,25 meter. Kondisi ini tentu berpengaruh langsung terhadap peningkatan intrusi air laut ke dalam akuifer bebas (Meyer et al., 2019; Nisa \& Yulianto, 2012). Karakteristik geomorfologi wilayah Kecamatan Sayung yang cenderung datar dengan dominasi material alluvial akan membuat daya resapan air asin semakin tinggi. Akibat sifat batuan alluvial yang cepat meresap air. Dengan demikian, tidak hanya intrusi air asin yang dewasa ini terjadi namun dimungkinkan pada kondisi lampau, kejadian air tanah asin di wilayah tersebut juga dapat terjadi karea air laut yang terjebak pada sedimen saat proses sedimentasi (connate water) (Widada, 2010).

Kondisi fisik Desa Sriwulan dengan dampak rob, genangan, dan intrusi air asin yang parah, diperburuk dengan tingginya kepadatan penduduk di desa tersebut. Berdasarkan data BPS Kabupaten Demak tahun 2019 Desa Sriwulan merupakan desa pesisir dengan kepadatan penduduk tertinggi. Dilansir oleh BPS Kabupaten Demak, jumlah penduduk Desa Sriwulan mencapai 12.482 jiwa dengan luas wilayah mencapai 4,02 $\mathrm{km}^{2}$, sehingga didapatkan bahwa kepadatan penduduk Desa Sriwulan mencapai 3.105 jiwa $/ \mathrm{km}^{2}$ (Badan Pusat Statistik Kabupaten Demak, 2019). Dengan kondisi wilayah yang cukup padat, kebutuhan air bersih akan selalu bertambah. Akibatnya masyarakat akan terus mengambil pasokan air tanah secara berlebihan dan lama kelamaan kondisi tersebut akan memperparah intrusi air asin di Desa Sriwulan.

Kejadian intrusi air asin dan tingginya tekanan penduduk di Desa Sriwulan ini tentu memerlukan perhatian lebih dari berbagai sektor. Adanya pemetaan distribusi cemaran air asin pada air tanah di Desa Sriwulan dapat menjadi langkah yang efisien dalam monitoring kejadian intrusi. Selain itu langkah ini juga bermanfaat sebagai warning system bagi masyarakat masyarakat dapat menjaga kondisi kualitas dan kuantitas air tanah sekaligus sebagai upaya untuk mengurangi laju penurunan muka tanah. Pengeboran air tanah yang tidak terkendali membuat intrusi air laut semakin cepat sehingga menimbulkan berbagai macam bahaya yang merugikan masyarakat.

Berdasarkan uraian di atas maka perlu dilakukan penelitian tentang distribusi sebaran air tanah tawar dan air tanah yang sudah tercemar air asin dengan metode geolistrik resistivitas yang kemudian dipetakan menggunakan software ArcGis. Metode geolistrik resistivitas merupakan metode pendeteksian formasi bawah permukaan sehingga keberadaan benda/material di bawah permukaan dapat teridentifikasi dengan melihat nilai resistivitasnya. Resistivitas ditentukan dari suatu tahanan jenis semu yang dihitung dari pengukuran perbedaan potensi antara elektroda yang ditempatkan di dalam bawah permukaan (Broto, 2012; Halik \& Widodo, 2009). metode geolistrik ini bersifat tidak merusak lingkungan, biaya relatif murah dan mampu mendeteksi perlapisan tanah sampai kedalaman beberapa meter di bawah permukaan tanah, khususnya untuk menentukan ketebalan lapisan serta litologi perlapisan batuan bawah permukaan (Sugito et al., 2010). Tujuan perspektif geologi dari metode geolistrik resistivitas untuk mengetahui ketebalan lapisan yang didapatkan melalui Vertical Electrical Sounding (VES) serta didapatkan pula gambaran lapisan struktur geologi secara komplit pada area penelitian (K. Waswa, 2019).

Dengan adanya peta persebaran distribusi intrusi air asin, maka dapat dilihat seberapa jauh intrusi air asin perkedalaman dan seberapa parahkah intrusi air asin terjadi (Hafiidh et al., 2018). Dengan kondisi ini masyarakat Desa Sriwulan dapat lebih mudah dalam menentukan kawasan yang 
sesuai sebagai tempat tinggal atau bangunan lainnya untuk menunjang kesejahteraan masyarakat di Desa Sriwulan itu sendiri.

\section{MATERI DAN METODE}

\section{Area Penelitian}

Penelitian ini dilakukan di Desa Sriwulan, Kecamatan Sayung, Kabupaten Demak (Figure 1). Kabupaten Demak merupakan salah satu kabupaten yang terletak di pesisir utara Jawa tengah. Sebagai daerah pesisir utara Jawa, potensi banjir rob sangat besar terjadi. Kondisi morfologi Demak yang cenderung datar, serta adanya kenaikan air laut setiap tahunnya, menjadikan beberapa desa di Kecamatan Sayung diantaranya Desa Sriwulan, Tambakroto, Gemulak, Bedono, Tugu, Surodadi, Banjarsari, Sidorejo dan lainnya mengalami dampak banjir rob. Hal ini sebagaimana survey dan interview yang dilakukan bersama warga setempat. Perkembangan kawasan industri juga turut andil dalam memperparah kondisi intrusi air asin akibat pengambilan air tanah dangkal yang melebihi kapasitas. Hal ini tentunya harus cepat diatasi, karena setiap harinya daerah yang terendam banjir rob dan intrusi air laut mengalami perluasan.

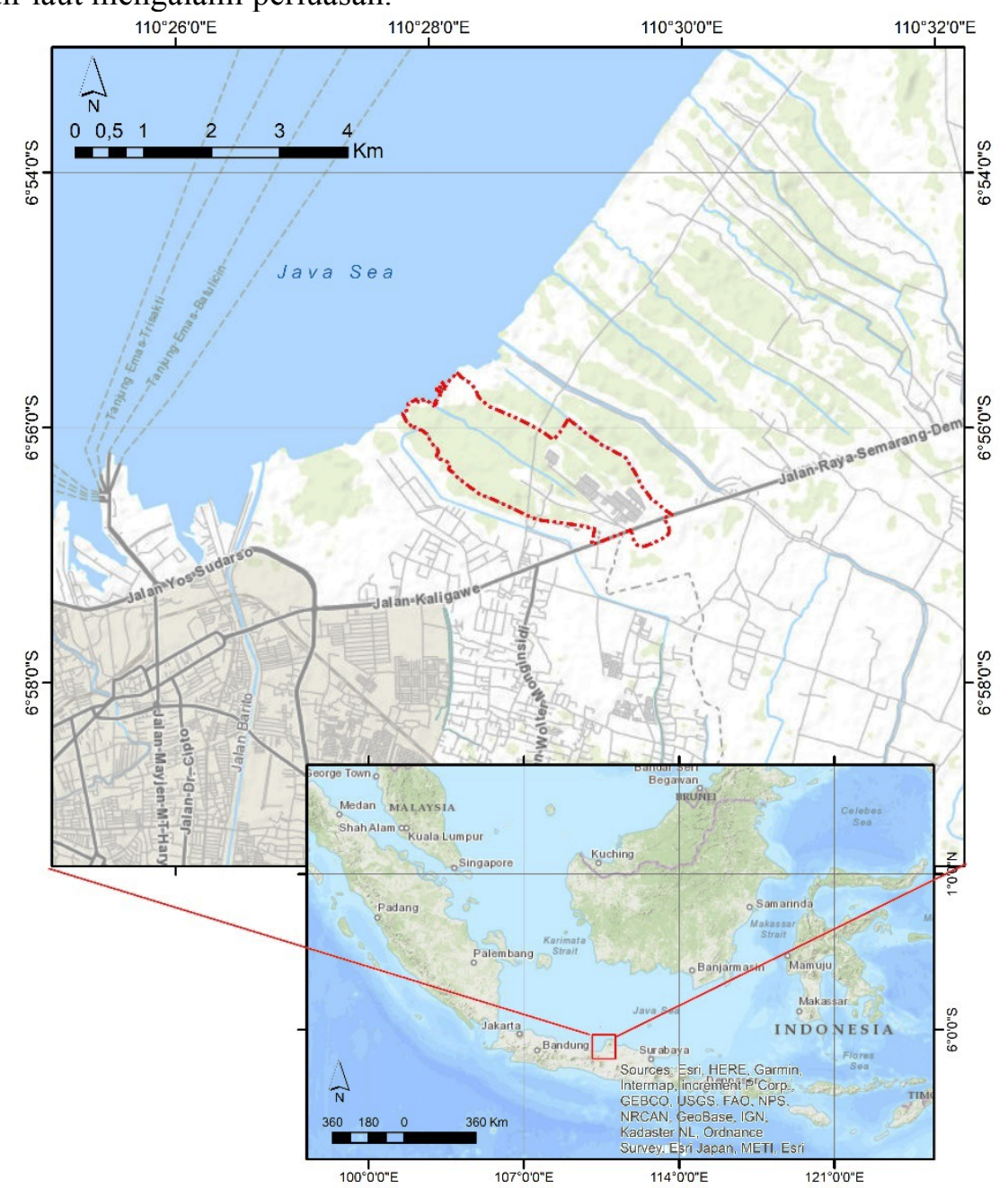

Figure 1. Research Location

\section{Materi dan Metode}

Dalam studi ini untuk akuisisi data geolistrik diharuskan mencari daerah yang bertanah dan tidak mempunyai lahan terbangun digunakan untuk membentangkan kabel geolistrik sepanjang 200 meter ke kanan dan kiri pada daerah yang akan diteliti.Dari hasil pengambilan data dilampangan 
akan didapatkan berupa data daya hantar listrik yang selanjutkan akan diolah menggunakan rumus sebagai berikut:

$$
\rho \mathrm{a}=\mathrm{R} \times \mathrm{K}
$$

Setelah didapatkan dari hasil perhitungan lalu diinterpretasikan menggunakan bantuan software IPI2WIN dan software Corel draw untuk mendapatkan litologi penampang batuan dari hasil data tersebut.Proses pengolahan data ditunjukkan dengan diagram alir sebagai berikut:

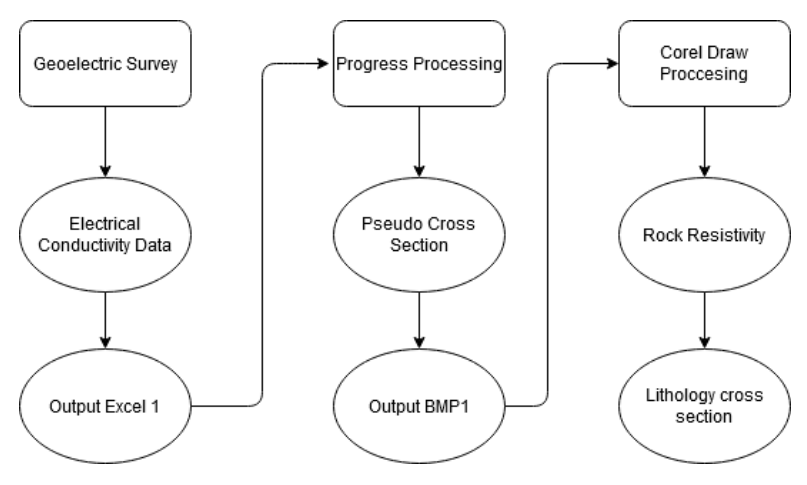

Figure 2. Research flow for resistivity analysis

\section{HASIL DAN PEMBAHASAN}

Berdasarkan hasil analisis resistivitas pada setiap stasiun yang dibuat berdasarkan hasil dari penampang litologi batuan ditemukan bahwa pada setiap lintasan mempunyai intrusi air laut yang ditunjukkan dengan resistivitas dibawah 3. Selain itu hasil analisis menunjukkan kecenderungan setiap lintasan pada litologi batuan berupa lempung (Table 1). Daerah pesisir biasanya kedalaman air tanah dangkal berada pada kedalaman 0.5 meter - 19 meter sementara untuk kedalaman air tanah dalam berada pada kedalaman 20 meter - 40 meter (Meyer et al., 2019). Pada hasil dari penampang litologi yang diinterpertasikan melalui peta intrusi air laut kedalaman 10 - 30 meter didapatkan bahwa pada ketiga penampang litologi secara keseluruhan mengalami intrusi air asin.

Table 1. Resistivity Condition for Certain Lithology

\begin{tabular}{cc}
\hline Lithology & Resistivity \\
\hline Sandstone saturated with freshwater & $30-150$ \\
Clay saturated with freshwater & $7-15$ \\
Sand/sandstone layer with clay & $20-40$ \\
intercalation & $8-25$ \\
Clay layer within sand lenses & $<3$ \\
Sand saturated with saltwater & $3-6$ \\
Clay/sand saturated with saltwater & $>1000$ \\
Dry sand & \\
\hline
\end{tabular}

Source: (Hodlur et al., 2006)

Hal ini menunjukkan bahwa air tanah dangkal pada wilayah Desa Sriwulan telah terkontaminasi air asin secara menyeluruh dan hanya menyisakan air tanah dalam yang besar kemungkinan belum mengalami kontaminasi dengan rata - rata pada kedalaman lebih dari 20 meter. Masyarakat pesisir memiliki kecendurungan untuk menggunakan air tanah dangkal, dan sebelum habis, masyarakat beralih ke PDAM atau memakai air tanah dalam atau sumur artesis (Purnama, 2019). Kecenderungan pemakaian air tanah dangkal ini dibuktikan pada stasiun 2,3,4,5,6,7 yang menunjukkan bahwa pada stasiun tersebut berada pada wilayah padat pemukiman (Figure 4). Bahkan pada penampang lokasi 1,2, 3 dan 7 intrusi air laut terjadi hingga kedalaman 50 meter dengan nilai 
resistivity kurang dari atau sama dengan 3 . Lokasi tersebut memang menjadi wilayah tumbuhnya industri yang kemungkinan melakukan eksplorasi air tanah secara berlebihan. Sedangkan pada lokasi 4,5 dan 6 terbilang lebih baik dari lokasi lainnya karena peristiwa intrusi air lautnya belum menyentuh hingga kedalaman 20-50meter meskipun secara visual wilayah tersebut digunakan sebagai pemukiman padat

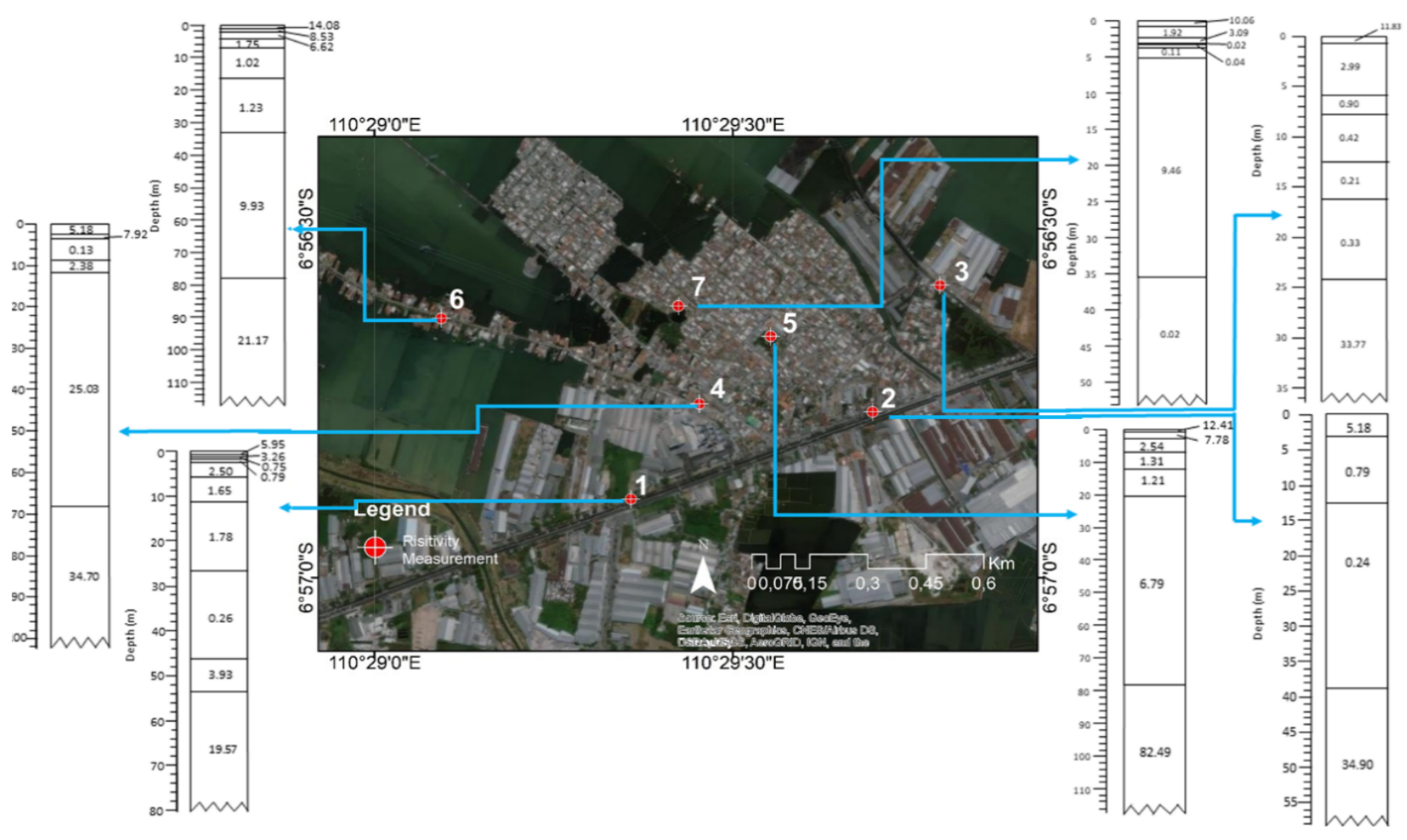

Figure 3. Result visualization of resistivity condition for each stations.

Meninjau dari segi batuan penyusunnya pada kedalaman $10-30$ meter pada sayatan $4-5-3$ yang memiliki litologi lempung sebagai penyusunnya. Jika melihat dari karateristik lempung sendiri, lempung memiliki sifat permeabilitas yang rendah. Hal ini terjadi karena lempung memiliki tingkat plastisitas yang sangat tinggi. Dengan memiliki sifat permeabilitas yang rendah, lempung sukar untuk melepaskan air. Pada waktu yang akan dating, kondisi ini akan menjadikan simpanan air asin pada tanah lempung menjadi connate water. Dengan demikian, akan lebih susah untuk mengembalikkan air tanah dangkal (Barlow \& Reichard, 2010; Winarno et al., 2018). Hal ini sebagaimana yang terjadi pada daerah pemukiman pada stasiun pengukuran 4,5 dan 3 . Pada stasiun $1-2$ dan stasiun $6-7$ diperoleh kondisi material dengan dominasi lanau. Berbeda dengan lempung, lanau memiliki permeabilitas yang tinggi sehingga dapat menerima dan meloloskan air secara cepat sehingga pada daerah ini sangat tergantung dengan pasang surut dan juga tergantung dengan kondisi garis ghyben herzbergnya (Hussain et al., 2015)

\section{KESIMPULAN}

Desa Sriwulan, Kecamatan Sayung, Kabupaten Demak, Jawa Tengah secara umum telah terdampak intrusi air asin. Hal ini juga diperparah sekaligus memperparah kejadian banjir rob dan genangan. Kejadiannya juga menjadi signifikan akibat adanya kenaikan muka air laut ditambah dengan kondisi topografi yang relatif datar dan kondisi demografi yang cukup padat. Metode terbaik untuk memetakan luasan lokasi terdampak intrusi air laut ialah menggunakan geolistrik resistivitas. 
Metode ini juga memberikan gambaran penampang kondisi geologi pada lokasi penelitian yang cukup akurat.

Secara lebih detail, setiap titik sampel telah mengalami intrusi air asin yang digambarkan melalui penampang resistivity dimana memiliki nilai konstanta dibawah 3 dengan didominasi oleh litologi lempung dan lanau pada kedalaman 10-30 meter. Kondisi tanah yang didominasi oleh lempung akan memperkecil proses permabilitas sehingga sukar dalam mendistrubusikan air tanah ke tempat lain. Hasil tersebut menunjukkan bahwa secara keseluruhan kondisi air tanah dangkal di Desa Sriwulan telah mengalami intrusi air laut dan hanya menyisakan air tanah dalam saja. Kondisi tersebut diakibatkan oleh pengambilan air tanah dangkal yang berlebihan terutama pada kawasan padat pemukiman dan juga adanya kawasan industri semakin memperparah intrusi air laut yang terjadi pada kawasan tersebut.

\section{DAFTAR PUSTAKA}

Badan Pusat Statistik Kabupaten Demak. (2019). Kecamatan Sayung Kecamatan Sayung. 63.

Barlow, P. M., \& Reichard, E. G. (2010). L'intrusion d'eau salée dans les régions côtières d'Amérique du Nord. Hydrogeology Journal, 18(1), 247-260. https://doi.org/10.1007/s10040-009-0514-3

Broto, S. (2012). Pengolahan Data Geolistrik Dengan Metode Schlumberger. Teknik, 29(2), 120-128. https://doi.org/10.14710/teknik.v29i2.1939

Desmawan, B. T., \& Sukamdi. (2012). Adaptasi Masyarakat Kawasan Pesisir Terhadap Banjir Rob Di Kecamatan Sayung, Kabupaten Demak, Jawa Tengah. Jurnal Bumi Indonesia, 1(1), 1-9.

Fletcher, R., Scrimgeour, R., Friedrich, L., Fletcher, S., Griffin, H., Environment World, U. N., \& Mangubhai, S. (2018). The Contributions of Marine and Coastal Area-Based Management Approaches to Sustainable Development Goals and Targets Technical Report UN Environment Regional SEAS Reports and Studies No. 205. In Citation: UN Environment.

Hafiidh, A. A., Saptomo, S. K., \& Arif, C. (2018). Sebaran Intrusi Air Laut di Kabupaten Indramayu, Jawa Barat. Jurnal Teknik Sipil Dan Lingkungan, 3(2), 69-76. https://doi.org/10.29244/jsil.3.2.69-76

Halik, G., \& Widodo, J. (2009). Pendugaan Potensi Air Tanah Dengan Metode Geolistrik Konfigurasi Schlumberger Di Kampus Tegal Boto Universitas Jember. Media Teknik Sipil, 8(2), 109-114.

Hendrayana, H. (2002). Intrusi Air Asin ke Dalam Akuifer di Daratan. Geological Engineering Dept., Faculty of Engineering, Gadjah Mada University, 1-15.

Hodlur, G. K., Dhakate, R., \& Andrade, R. (2006). Correlation of vertical electrical sounding and borehole-log data for delineation of saltwater and freshwater aquifers. Geophysics, 71(1), 10-20. https://doi.org/10.1190/1.2169847

Hussain, M. S., Javadi, A. A., \& Sherif, M. M. (2015). Three Dimensional Simulation of Seawater Intrusion in a Regional Coastal Aquifer in UAE. Procedia Engineering, 119(1), 1153-1160. https://doi.org/10.1016/j.proeng.2015.08.965

Irham, M. N., Achmad, R. T., \& Widodo, S. (2006). Pemetaan Sebaran Air Tanah Asin Pada Aquifer Dalam Di Wilayah Semarang Bawah. Berkala Fisika, 9(3), 137-143.

K. Waswa, A. (2019). Application of Electrical Resistivity Method in Mapping Underground River Channels: A Case Study of Kabatini Area in the Kenyan Rift Valley. Universal Journal of Geoscience, 7(1), 114. https://doi.org/10.13189/ujg.2019.070101

Mas Pla, J., Ghiglieri, G., \& Uras, G. (2014). Seawater intrusion and coastal groundwater resources management: examples from two Mediterranean regions: Catalonia and Sardinia. Contributions to Science, 10(2), 171-184. https://doi.org/10.2436/20.7010.01.201

Meyer, R., Engesgaard, P., \& Sonnenborg, T. O. (2019). Origin and Dynamics of Saltwater Intrusion in a Regional Aquifer: Combining 3-D Saltwater Modeling With Geophysical and Geochemical Data. Water Resources Research, 55(3), 1792-1813. https://doi.org/10.1029/2018WR023624

Nisa, K., \& Yulianto, T. (2012). Aplikasi Metode Geolistrik Tahanan Jenis Untuk Menentukan Zona Intrusi Air Laut di Kecamatan Genuk, Semarang. 15(1).

Nugroho, H., Indriastuti, A. K., Wibowo, M. A., \& Hermawan, F. (2020). Penanganan Erosi Pantai dengan Penanaman Mangrove Di Desa Bedono Kecamatan Sayung Kabupaten Demak. 2(1), 53-59.

Octonovrilna, L., \& Pudja, I. P. (2009). Analisa Perbandingan Anomali Gravitasi Dengan Persebaran Intrusi Air Asin (Studi Kasus Jakarta 2006-2007). Jurnal Meteorologi Dan Geofisika, 10(1), 39-57. https://doi.org/10.31172/jmg.v10i1.32

Ode, I. (2011). Intrusi Air Laut. Bimafika, 3, 266-271. 
Purnama, S. (2019). Groundwater Vulnerability from Sea Water Intrusion in Coastal Area Cilacap, Indonesia. Indonesian Journal of Geography, 51(2), 206-216. https://doi.org/10.22146/ijg.18229

Sugito, Irayani, Z., \& Jati, I. P. (2010). Investigasi Bidang Gelincir Tanah Longsor Menggunakan Metode Geolistrik. Berkala Fisika, 13(2), 49-54.

Trihatmoko, E. (2020). Dinamika Wilayah Kepesisiran Jawa Tengah Bagian Utara dengan Pendekatan Geomorfologi.

Widada, S. (2010). Gejala Intrusi Air Laut di Daerah Pantai Kota Pekalongan. Gejala Intrusi Air Laut Di Daerah Pantai Kota Pekalongan, 12(1), 45-52. https://doi.org/10.14710/ik.ijms.12.1.45-52

Winarno, T., Kurniasih, A., Marin, J., \& Kusuma, A. I. (2018). Identifikasi Jenis dan Karakteristik Lempung di Perbukitan Jiwo, Bayat, Klaten dan Arahannya sebagai Bahan Galian Industri. Teknik, 38(2), 65. https://doi.org/10.14710/teknik.v38i2.12942 